\title{
Child Prodigies Exploring the World: How Homeschooled Students Narrate Their Literacy in the Digital Archive of Literacy Narratives
}

\author{
Alicia A. McCartney
}

Follow this and additional works at: https://digitalcommons.cedarville.edu/

english_literature_modern_languages_publications

Part of the Curriculum and Instruction Commons, and the Language Interpretation and Translation

\section{Commons}

This Article is brought to you for free and open access by DigitalCommons@Cedarville, a service of the Centennial Library. It has been accepted for inclusion in English, Literature, and Modern Languages Faculty Publications by an authorized administrator of DigitalCommons@Cedarville. For more information, please contact digitalcommons@cedarville.edu. 


\title{
Child Prodigies Exploring the World: How Homeschooled Students Narrate their Literacy in the Digital Archive of Literacy Narratives
}

\author{
Alicia A. McCartney - Baylor University
}

\section{KEYWORDS}

homeschooling; child prodigy narrative; literacy narrative;

Digital Archive of Literacy Narratives (DALN); active double-voiced discourse

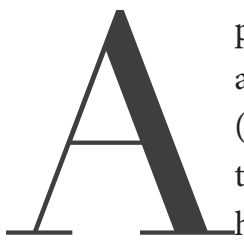

pproximately 1.8 million students in the United States are homeschooled, according to 2012 data from the National Center for Education Statistics (Redford et al.). This group, which represents 3.4 percent of all K-12 students in the US, is growing increasingly more diverse, making it difficult to describe the homeschooling experience monolithically (Grady, "Measuring"). Researchers have only begun to examine how these homeschooled students reflect on their own literacy development, especially after these students enter college. From the Digital Archive of Literacy Narratives (DALN), I gather and analyze eighteen literacy narratives of currently and formerly homeschooled students. This article explores how these students reflect on their own developing literacies, especially as they contrast their experiences with those of their traditionally-schooled peers.

These narratives hold value for college educators, who are increasingly receiving formerly homeschooled students into their classrooms. As Phillip P. Marzluf notes, these students may hold literacy values and assumptions that conflict with those of their instructors (49). By examining these narratives, I intend to add more voices to the emerging conversation about homeschooling and literacy. Additionally, these narratives highlight the diversity of homeschooling experiences in ways that challenge common assumptions about the homeschooling community.

As homeschooled students enter college in increasing numbers, researchers have observed that prevalent myths and stereotypes about homeschooling and homeschoolers persist, though homeschooling is becoming increasingly common. In 1985, only sixteen percent of Americans believed homeschooling was a good idea (Lines 83 ). Although this approval rating has steadily climbed over time, Cynthia Drenovsky and Isaiah Cohen observe that homeschoolers are often assumed to be "backward," "on the fringe," or extremely conservative, and they note that strong proor anti-homeschooling biases in the literature skew data towards either this stereotyped picture or an overly positive one. Michael Romanowski highlights four common "myths" about homeschooling: that homeschooled children are "social misfits," that their educational experiences occur in isolation, that they have difficulty being admitted to colleges, and "that most people homeschool only for religious reasons" (125-128). Though these myths persist, Romanowski argues that they do not 
reflect the majority of homeschooled children or homeschooling practices.

Romanowski's final myth-that most homeschool only for religious or ideological reasonsfinds its source in part from Jane Van Galen's 1988 binary model, which examines the reasons people homeschool. Van Galen divides homeschoolers into two categories: ideologues (those who disagree primarily with the public school system's ideology and wish to teach their own values) and pedagogues (those who disagree primarily with the public school system's educational methods or quality and believe they can provide their children a better education). Yet Kariane Marie Nemer argues that Van Galen's binary division between ideologues and pedagogues does not reflect the multiple, complex, and often overlapping motives of homeschooling parents. Nemer proposes an alternative to Van Galen's typology: a four-quadrant model that plots individuals' motivations on an $\mathrm{X}-\mathrm{Y}$ axis to better represent ranges of overlapping ideological and pedagogical motives instead of artificially dividing them (9).

Because parents homeschool for different reasons, they also engage in a variety of literacy practices. Jennifer Altieri examines practices within a Catholic homeschooling group via parental interviews. She observes that the parents emphasize reading aloud, and incorporate media such as newspapers and magazines "in order to make reading relevant" (111). Literacy practices include reallife scenarios such as taking educational trips, "taking notes on the sermon at mass, keeping dialogue journals, and writing letters," including letters to elected representatives to encourage policy change (112). Courtney Wooten finds that non-specialist homeschooling parents "engage in an imaginative construction of college writing" as they attempt to prepare their students for college (1).

The main societal measure of homeschooling literacy currently appears to be how homeschooled students perform once they enter college. Multiple studies have suggested that formerly homeschooled students who attend college equal or surpass their peers academically, emotionally, and socially. In a study of 408 students at a small Catholic university, Marc Snyder notes that the 129 formerly homeschooled students in the cohort had higher ACT and SAT scores and overall first-year GPAs. Drenovsky and Cohen observe that homeschooling stereotypes had no measurable effect on the self-esteem of the homeschooled students in their study. These homeschooled students were also less depressed and viewed their college experience more positively than did their traditionally-educated peers. Jeanine SanClemente's study of eleven formerly homeschooled female college students finds that they felt on par with their peers academically and socially. Though these women felt as if they had been "raised in a different culture," they were more confident in their academic ability, believed they could be more self-directed in school, and felt closer to their families (SanClemente 4). Likewise, Karl Payton and Joyce Scott find that homeschooled students are no more likely than their traditionally-schooled peers to have social anxiety or communication apprehension.

However, homeschooling literacy practices-especially those practices of conservative, religious, ideologically-motivated homeschoolers-have also given rise to occasional concern. Phillip P. Marzluf argues that these students are less likely to engage with the ideas they encounter in college because they have practiced "frontier literacy" and because homeschooling involves "retreating from public institutions and constructing literacy and social boundaries of their own" as a flight from "vernacular voices" and "an objection to the social responsibilities mandated by the public 
sphere" ("Literacy" 75). These concerns, especially because they directly affect instructors of college composition, merit further exploration.

As Nemer has observed, much more research still needs to be conducted on homeschooling and literacy, and this research needs to take into account "the rich and fascinating range that presently exists among homeschoolers" (4-5). With the exception of Marzluf, authors focus primarily on reasons for homeschooling, homeschoolers' academic preparation for college, or their literacy practices while still homeschooling. There is a need for more research that explores how college students look back on their homeschooling literacy practices once they have entered a traditional school environment. Using the Digital Archive of Literacy Narratives (DALN) as a source, my current research seeks to fill this gap by examining how currently and formerly homeschooled students understand and narrate their homeschooled literacy acquisition.

To provide material for this study, I retrieved a body of literacy narratives from the DALN that reflect a diverse cross-section of homeschooling experiences. Accounting for keyword variants, I submitted a query in the database for "home school" OR homeschool OR homeschooled OR homeschooled OR homeschooling OR "home schooling" OR home-schooling. The search retrieved fifty results, though not all were relevant. I excluded false positives such as narratives whose authors had supplied the metadata tags "home" and "school" but were not homeschooled. I also excluded narratives by homeschooling parent-teachers, since my focus for this study is the literacy experiences of homeschooled students. I then limited the pool of narratives further by selecting only narratives that explicitly reflect on the authors' homeschooling experiences. For the purposes of this study, I have accepted authors' decisions to label their experiences as primarily "homeschooling" - even if they record participating in some activities associated with traditional schooling, such as public school athletics or community college classes, or if the experiences they describe seem to more closely align with accepted definitions of unschooling. ${ }^{1}$

The body of eighteen remaining narratives includes a variety of formats: written texts, video and audio interviews, self-recorded video, and audio narratives. A majority of these narratives (fourteen) are written by women, with three written by men and one by an author whose gender is unknown. Most of these authors were born in the late 1980s and early 1990s; the oldest student who provided her age was born in 1979, and the youngest was born in 1999.

It is important to remember in any study of the DALN that the uploaded narratives are shaped by rhetorical context. Krista Bryson has noted that the DALN's design unintentionally reinforces traditional representations of literacy as reading/writing. As a potential counter-bias, some of the narratives I examined appear to have been completed as assignments for college courses focused on literacy. Some even include names of assigning instructors or reference class texts and terms such as Deborah Brandt's "literacy sponsors." This suggests that at least some of these students may be producing the kind of "academically correct" literacy narrative that they imagine their professors will want to read, or that they are using tools and concepts from literacy studies to interpret their own experiences.

Bryson urges researchers using the DALN to remember that "representations of culture and identity can be analyzed for what they reveal about individual and cultural perceptions in one 
narrative moment" and argues that "the construction of literacy narratives is further complicated by the fact that narrators are not only self- and culturally-positioned . . . they are positioned by their audience and the context in which their stories are elicited" (256). This complication can be coupled with the fact that the individualized nature of homeschooling makes it difficult to generalize about literacy experiences in the same way that one might generalize about public school or private school literacy practices and experiences. Additionally, it may not be possible to draw broad conclusions about homeschoolers' contributions to the DALN because this study may exclude some narratives if their authors did not tag them with the searched keywords.

Because it is impossible to generalize from this small sample of a diverse population, I treat these narratives as "curious texts" (Hart 78) and apply a generative criticism model: coding the artifacts by noting interesting features and grouping them to allow similarities, patterns, and themes to emerge. The process of generative criticism, outlined by Sonja Foss, allows the texts themselves to suggest multiple interpretive frameworks, such as Bakhtin's "active double-voicing" and the "child prodigy" narrative structure (411). These frameworks reveal several patterns that both reinforce and expand the current homeschooling literature. I find that these homeschooled students highlight a diverse network of "literacy sponsors"-which Deborah Brandt defines as "any agents, local or distant, concrete or abstract, who enable, support, teach, model, as well as recruit, regulate, suppress, or withhold literacy" (19). These literacy sponsors, both inside and outside narrators' families, reflect, expand, and challenge traditional ideas of where and how literacy is acquired.

Additionally, homeschoolers recall participating in a wide variety of literacy practices that both respond to and redefine those of the "traditional" classroom. Many writers frame their narratives using the "child prodigy" literacy structure, as identified and defined by Alexander and Paterson. Finally, four narratives reveal problems that can occur in homeschooling, such as a parent's perceived lack of authority, and, in two cases, a tendency to trap students in unhealthy family environments. Despite these exceptions, most narratives reveal their authors' family networks as places of vibrant literary sponsorship; and a few students narrate the "pedagogic violence" that may occur when they transition from these warm family environments into traditional secondary schools (Worsham 121).

Overall, I find that as participants in a non-dominant mode of education, these homeschoolers feel the need either to justify or to repudiate their literacy acquisition process against the dominant group. The authors of these narratives engage in an act of rhetorical positioning that Bakhtin describes as "active double-voiced discourse," as they anticipate and preempt criticism from an imagined, hidden interlocutor (Baxter 32). In her summary and exposition of Bakhtin's concept of "active double-voicing," Judith Baxter notes that its defining characteristic is "a hostile or antagonistic intention as a reaction to the 'threat potential' of other people's words . . . . a linguistic shield, a form of speaker protection against the anticipated criticism of others" (32). Many narratives reveal the underlying sense that these students' "homeschooling literacy" is illegitimate, on the margins, vulnerable to attack. Even after they have entered college, many students with positive homeschooling experiences still feel the need to defend the legitimacy of their literacy. 


\section{The World As Classroom: Literacy Outside The Box}

The narratives I selected reveal that homeschoolers both participate in and redefine traditional classroom methods of literacy instruction. One of the most common traditional sites for literacy is the public library, mentioned in four different narratives. The library emerges as a key literacy sponsor in these narratives. It provides homeschooled students access to curriculum resources and also allows self-directed exploration.

Homeschoolers in these narratives recall reading with parents, surrounding themselves with library books, and taking frequent library trips. The library was an almost-daily destination for Stephen Carradini, who would complete math and science lessons at home in the morning and spend his afternoons reading self-selected books at the public library. He recalls being fascinated by cultures and geography and choosing to read books about countries like Moldova and Congo. Those who could visit the library less frequently often recount bringing home the maximum number of books they were allowed to check out. Muslimah Muhammad recalls that she and her siblings would share the fruits of these maxed-out library trips: "At the time, it was 50 books, max. So we'd get the 50 books, and we'd have them all read, switched back and forth, so there's so many books that I've read that I can't really . . . I couldn't possibly give you an estimation of how many books I've read." The library allowed Muhammad to access more books than her family would have been able to purchase. Library books also created a sense of public property rather than individual ownership: these books were meant to be shared among members of her family rather than simply belonging to one sibling.

Libraries may have particularly attracted these homeschoolers because they are "third spaces" that offer authority structures similar to traditional classrooms but with fewer restrictions. James K. Elmborg observes that libraries are not ideologically neutral spaces; rather, both library and classroom are "dominated spaces" with "educators' conceptual structures and rules defining acceptable and right activities" (347). While the rules of these dominated spaces give many who enter a sense of "security and comfort," Elmborg observes that these spaces can also embody a "spirit of freedom and adventure": "Indeed, for many users the extreme orderliness of the library provides a thin veneer over an otherwise seemingly endless and sometimes chaotic context for discovery of the unknown" (347; 346). ${ }^{2}$ Elmborg argues that libraries can be viewed in two ways: as either "a highly articulated and settled place, with librarians as enforcers of the codes and orders of behavior, or an indeterminate and open space with the potential for adventures and surprises. The distinction exists in the mind of the user and the librarians" (346). The homeschoolers in this study who mention libraries tend to view them as indeterminate, open spaces with potential for adventure rather than structured or restricted spaces. The fifty-book restriction at Muhammad's library, for example, paradoxically encouraged her and her siblings to routinely take pride in maximizing the number of books they checked out, and it potentially caused them to make more frequent trips. Another student, Carlee Mabrey, focuses on the library as a sacred repository of knowledge: "After all, since church was sacred because it contained one book written by an all-knowing being, then certainly a library was sacred because it contained thousands of books written by people who were, although not all-knowing, at least a lot smarter than I was." Mabrey's narrative reveals that she used the library as a site for wonder 
and exploration and that it became a key sponsor in her self-directed literacy adventure.

Though most of the students identify their backgrounds as middle class, the library also provided a free or cheap resource to students growing up in poverty. Amanda Joy, who narrates her experiences of homeschooling in Appalachia, found that the library was often the only sponsor of her literacy:

Books were my life. The local library often ran basement book sales - hardcover 50థ, paperback 25 4 . I would fill cardboard boxes with new-to-me books - autobiographies, castoff text books, novels, and the little old ladies who ran the sale would chuckle as they tallied up the totals. I had the freedom to explore whatever topic was of interest to me and I found myself writing reports on microeconomic theories, herbology and Anne Frank. We may not have had electricity or indoor plumbing, but we had books and it was in those books that I could escape the poverty of my surroundings.

Without the traditional structures of a classroom, these homeschoolers enter the library with a more open, exploratory mindset; the topics of Joy's reading, for example, centered around whatever interested her. As I discuss later, Joy's experience of homeschooling differs from many of these homeschoolers' narratives because of her family's poverty and the largely unsupervised nature of her homeschooling experience. Though she is the only author to mention her low-income background, she is also the only person who recalls buying books from a library book sale rather than checking them out for free. These library purchases gave her a sense of ownership and control over her own literacy. Joy-like Mabrey, Carradini, and Muhammad-records gaining agency from the library's literacy resources.

In addition to library visits, another traditional classroom literacy activity that homeschoolers often appropriate and re-define is the field trip. As opposed to the traditional classroom field trip, which happens rarely, homeschoolers recount more frequent, spontaneous, and varied field trip experiences. Homeschoolers often used these field trips as chances to interact with other homeschooling families or groups, and students distinctly remember these hands-on learning experiences.

Dallas Reynolds recounts field trips to museums and historical sites as a key sponsor in her literacy. "I became literate by interacting with my environment," she says, describing how she and her mother studied the American Civil War by visiting historic battlefields. Like Reynolds, Megan Cardenas describes taking field trips with other homeschoolers once a month. One of these, a daylong space museum trip, required her to "apply" for the job she wanted on the "spaceship":

Of course, I wanted to be the captain. I wrote a long essay explaining why I should be the captain and how I was a natural born leader, keep in mind I was only 8. I got the position and my duties included going around the museum with my co-captain and making sure that everything was running smoothly. I had a checklist and a big appetite for information. I went around to all the stations and made sure everyone was on schedule.

This literacy activity gave her a sense of responsibility and also a sense that writing could bring reallife rewards.

In addition to the space museum field trip, Cardenas recalls learning history via a field trip to the Ohio Historical Society. On this trip, learning was a whole-body experience: "You dressed 
up in clothing only from that period and packed a lunch that kids in that time would traditionally eat. We were taught in the school that was located in the historical village. We used chalk and chalk boards to learn and sat at the old desks." Using her body to interact with a space allowed Cardenas to imaginatively participate in constructing history. Sitting in the historic school building, writing with individual chalk slates, she began to imagine what literacy was like for people of the past, and this memory stayed with her into college.

While many homeschoolers took field trips to traditional literacy sites (such as museums or historic landmarks), some took a more nontraditional approach. Lynn Simmons notes that an activity as routine as visiting a playground could become a field trip. During these trips, she learned social and writing skills by observing other people and describing them: "Everything was some kind of learning environment ... we would go to like a playground, a park, and we would watch people doing their daily routines, and we would take notes of it." The outside world offered limitless possibilities for learning; Komysha Hassan recalls taking her Audubon field guides outside her home to practice identifying wildlife. Field trips are broadly defined because any space can be a site for literacy development.

In addition to field trips and library visits, students recount creative ways their home educators would gamify literacy learning. For Julia Fleming, literacy learning came as part of a video game: her parents would allow her to play her brother's Nintendo's "Animal Crossing" as a reward, and she learned to read partly because the animals would talk in "lengthy paragraphs." Lynn Simmons' mom would assign her classic movies, such as My Fair Lady, in order to teach her literary terms such

"By re-shaping practices associated with the traditional classroom, homeschoolers move beyond the boundaries of both home and school. . . Though many of these homeschoolers remember participating in some traditional classroom experiences, such as field trips or library trips, they also recall redefining these traditional practices in ways that fit their personalities and learning styles. Homeschooled students who recall creative learning practices are more likely to record positive experiences with literacy than those who recall learning from textbooks, worksheets, or flashcards." as climax and plot. She recalls taking notes on these movies and writing papers about them from fifth to seventh grade. For Simmons, there were no strictly defined boundaries between school time and free time; instead, their family would always be discussing what they had learned. Simmons' "recess" was watching the educational television show Reading Rainbow during lunch, and her mom would quiz her and her siblings, "even driving the car on the way to McDonalds." Elisa Johnson recounts enjoying spelling bee competitions with her older siblings. Her mother would give a spelling word to her older siblings first, and if they both missed the word, Johnson would often be able to figure it out as the third sibling in line. All three authors associate reading and 
writing literacy with play rather than punishment; literacy becomes a game (and sometimes a sibling competition), rather than a chore.

By re-shaping practices associated with the traditional classroom, these homeschoolers move beyond the boundaries of both home and school. Hassan writes, "The world was my classroom, everything and everyone was a study subject . . . . The biggest contribution of homeschooling to my learning was the number of ways things could be studied, and thus necessarily were." Hassan's description of the world as her classroom reflects the way that many of these homeschooled students perceive their homeschooling literacy practices. Though many of these homeschoolers remember participating in some traditional classroom experiences, such as field trips or library trips, they also recall redefining these traditional practices in ways that fit their personalities and learning styles. Homeschooled students who recall creative learning practices are more likely to record positive experiences with literacy than those who recall learning from textbooks, worksheets, or flashcards. ${ }^{3}$

Even as homeschooled students take pleasure in redefining traditional literacy practices, their non-traditional literacy practices could open them up to criticism, especially from mainstream educators, more traditional family members, or even people in the community who are skeptical of homeschooling's viability as an educational option. Is a child people-watching at the park or watching movies - as Lynn Simmons did - truly gaining literacy, compared to a child who is learning in a public school environment? Anticipating potential criticism from an imagined audience, homeschoolers in these narratives often feel the need to engage in active double-voicing to defend themselves.

For example, Komysha Hassan responds to stereotypes about her learning practices by describing how her parents exceeded the standards they were legally required to meet: "Parents of home-schooled children who submitted their paperwork for school board or teacher review and took voluntary term tests, took pains to make sure that the body of work superseded that required by the public school system; and therefore it always did by lengths (case and point: a 56 page fictional story for my 11th grade English). It was hard work sometimes." Her references to her parents' efforts serve to justify the education they were providing her, and she assumes that many of her homeschooling peers are doing the same. Her use of the plural generic "parents of home-schooled children," indicates that she feels the need to defend homeschooling itself as a legitimate method of acquiring literacy. She imagines herself as part of a group of homeschoolers, all of whom are taking similar pains to excel. Perhaps this need to defend homeschoolers as a group-generalized from her own experiences-comes from an underlying sense that any attack on homeschooling delegitimizes her own literacy acquisition.

Some of these students respond to an imaginary critical audience by using their or their parents' success in traditional higher education-college-as a benchmark. Lynn Simmons, who recounts learning via people-watching and movies, writes that her mother, who was both a home educator and a college English professor, was a hard grader. Simmons considered it an achievement to earn a $\mathrm{B}$ on essays she wrote for her mom during her homeschooled high school experience. Thanks to her homeschooling education, Simmons states that she routinely received As in later college composition courses. Likewise, Megan Cardenas (who recounts her application to be spaceship captain) believes that college writing is too easy for her because of her homeschooling background. She asserts her 
mom's suitability as an educator because she "majored in education in college and was fully equipped to teach her five kids." The words "fully equipped" anticipate criticism and respond preemptively.

Judith Baxter has observed that active double-voicing can indicate "linguistic insecurity," but also that it can serve as "a linguistic sword, a weapon in the battle of words to gain ascendancy" (32). Thus, active double-voicing paradoxically reveals both insecurity and expertise, as writers carefully use language to situate themselves in positions of control over what they perceive as a "difficult and threatening discursive encounter" (Baxter 32). In these narratives, active double-voicing reveals that the authors view themselves as rhetors on the margins and use their literacy narratives to speak back to dominant discourses about where, and how, literacy develops best.

\section{Homeschoolers As Self-Identified Child Prodigies}

Another of the common rhetorical strategies some students use to defend their education is the child prodigy narrative. Alexander describes the child prodigy narrative as one in which the subject "excels at reading and writing from an early age and is put on display for others to see his or her brilliance and intellectual acumen; [this type of narrative] includes tales of prolific reading, trips to the library or bookstore, abundant exposure to literate texts, and being read to by parents" (615). She notes that authors of child prodigy narratives depict their literacy acquisition process as "exceptional," and that these literacy narratives often highlight "joyful moments when reading and writing were fun, personal, and social" (619). The child prodigy narrative is a subset of the success narrative: one's success later in life results from one's early, recognized success with literacy activities. Of the eighteen narratives this study examines, six can be clearly categorized as "child prodigy" narratives. ${ }^{4}$

Sometimes these child prodigy narratives are merely stated, and other times they are more developed. Jeremiah Harbour, born in 1998 and homeschooled from first through third grade, attributes his success in public high school to his early homeschool literacy acquisition. He writes, "Reading and writing are simple concepts that define part of who I am. Being taught at the very early age of four and five, I was easily understanding every concept later on." Dallas Reynolds, who began reading at age 2 , similarly argues that her early success with reading gives her an advantage over her college classmates: "Now I read everything I can," she says. "In a lot of English classes I've already read everything on the syllabus."

A longer example appears in the written narrative of Bethany Frantsen, born in 1997 and attending St. Olaf College at the time her narrative was published. Frantsen's narrative primarily focuses on her practice of journaling, which she sees as an opportunity to break free from the performative nature of literacy. She introduces her narrative by stating, "Throughout my academic life, unless I have been given specific instructions, I have always asked the question 'What do you want from me? What do you want me to do?' I aim to please." Frantsen contrasts structured and performative academic writing - writing to please others - with the free nature of her personal writing, writing only to please herself. In the final paragraph of her narrative, she discusses the "special" nature of her early acquisition of reading literacy: 
Learning to read at home from my parents was something special that I realize that I now took for granted. I learned to read when I was 4 years old, by looking at the words of the books my mom or dad would read to me every night. My mind was captivated by the letters that turned themselves into words, and from there the possibilities were endless. I was dying to get to use these tools myself. These early memories of learning to read really matter, because it was where I began to develop my literacy. Little did I know then of how far I would come. And still, little do I know now of how much more I have to learn.

Though she "took for granted" her home-taught reading skills, she retrospectively constructs this experience as "special," implicitly in contrast to her college peers. Her literacy acquisition was social, warm, and exciting, and those positive associations with both reading and writing continue into college. She acknowledges that she has more to learn, but implies confidence in her ability to do so because of her literacy skills.

The "child prodigy" narrative is associated not only with reading, but also with writing. Hassan recalls growing interested in writing when, at age six, she watched the O. J. Simpson trial on television. She writes, "An avid reader already, and not so occasional writer, this case was a goldmine of literary stimulation with its dizzying display of articulated arguments and flamboyant oratory flourishes; my perspective was permanently changed as a writer and reader.... Words were not simply recordings of observations or expressions of feelings but they were statements about events, conclusions and arguments, powerful enough to send a man to the gallows or set him free." From the age of five, she wrote "legal letters" to her family and received both praise and critique: "They were always very receptive to it; encouraging me to continue and challenging me to be better." As she grew older, she would write reports on various news stories for her family: "For every story I had a report, multiple ones even, which my parents would have me read aloud to the family, and they were always accorded generous praise." The praise of her parents reinforced her position as a child prodigy and encouraged the continued development of her literacy skills.

In addition to support and praise, Hassan's child prodigy narrative recounts competition with her older siblings. From ages 6 to 10, she would argue heatedly with them about current events. Literacy became a way for her to prove herself, to win. She recalls, "I was determined to validate my opinions not just to my parents but to my siblings as well. I needed to make an argument and bolster that argument with evidence, precedent. Make it irrefutable, unarguable. This was how I could compete and prove myself. This was how to win a case." These early literacy displays were positive and communal, and key were the social recognition, rivalry, and reinforcement from her family's literacy sponsorship.

An element of competition also appears in Carlee Mabrey's literacy narrative, entitled, "Me vs. Everyone: Why Being an English Major Makes Me Smarter Than Everyone Else." A college student at Ohio State University, Mabrey attributes her early literacy acquisition to her desire to compete with her cousin. She writes,

For instance, one of my earliest memories involves how my inability to read made me feel stupider and inadequate in comparison to my cousin. I had to have been about three years old when my cousin Tiffany took me and my siblings to a high school basketball game 
and treated us to a few pieces of candy at the concession stand. I remember very clearly watching my cousin tell me what kinds of candy were available to me by reading them off a sign at the stand, and the fact that she could tell what they were offering and I could not bugged me .... I remember looking at what I now recognize as words on the sign and thinking "how does she know what that says? Why don't I know what that says?" Even though I was over ten years younger than Tiffany, I still thought it was wrong that she should have control over knowing what kind of candy I could pick because she had a means of understanding that I didn't. This memory imprinted the idea in my mind that reading was the key to understanding things that other people knew, so I learned at a young age to value the knowledge that reading had to offer.

Just as Hassan became a better writer at a young age to win arguments with her siblings, Mabrey learned to read in order to gain equal footing, to gain power. She explains,

I've always liked [to] be smart because when I know more than everyone around me, I have the upper hand in our interactions and therefore have no reason to feel shy, be scared of or feel intimidated by anyone else. When I know that I'm smarter than someone, I'm in control of the situation .... Maybe this makes me a competitive control freak with a superiority complex, but at this point I've just learned to accept that about myself.

Although Mabrey writes that she is aiming to be smarter than everyone else, the example that she provides reveals her at a position of inequity with her cousin, seeking a position of equality. In an example of active double-voicing, Mabrey's narrative anticipates a reader's potential criticism of her

"These students employ the child prodigy narrative to justify their literacy, positioning their accounts against real or imagined interlocutors who may believe their literacy acquisition is illegitimate because it deviated from the mainstream educational model.

These findings may challenge the research of Drenovsky and Cohen, who argue that stereotypes do not affect homeschoolers' selfesteem. The level of justification that these six students found rhetorically necessary suggests that they perceive themselves as criticized in college by fellow traditionally-educated students or by their professors." attempt to gain power via literacy acquisition ("Maybe this makes me a competitive control freak with a superiority complex") and preempts this criticism by owning the label: "I've just learned to accept that about myself." She also defends her decision to major in English against an imaginary interlocutor whom she imagines to, "sneer and condescendingly claim that English is an artsy-fartsy major that has no real application." Active double-voicing becomes a strategy for her to exert power over her own literacy narrative and its reception, even as she reveals that it was homeschooling that led her to love reading and 
realize "the whole world was open to me."

What does the subject gain by positioning themselves as "special" because of their early literacy acquisition? Stephanie Paterson writes that the child prodigy narrative is "a (perhaps) defensive, protective way to position the self against questioning or critique" (103). She observes, "Sometimes I think these narratives are written in a slightly defensive posture by students who are a little intimidated by the first-year composition class. By presenting a flawless self they attempt to posit at least a textual version of the self that is untouchable and invincible, or at the very least-powerful" (Paterson 118). I suggest that many students in this sample who employ the child prodigy narrative use it to justify their literacy, positioning their accounts against real or imagined interlocutors who may believe their literacy acquisition is illegitimate because it deviated from the mainstream educational model.

This study's findings may challenge the research of Drenovsky and Cohen, who argue that stereotypes do not affect homeschoolers' self-esteem. The level of justification that these six students found rhetorically necessary suggests that they may perceive or anticipate criticism in college from fellow traditionally-educated students or professors. Cardenas, for example, begins her narrative by defending herself: "Homeschooled: This word often scares people and is often associated with the phrase socially awkward." This introduction indicates that she is aware of the ways that others categorize her and that she feels the need to address audience preconceptions before she can share a valid literacy experience. The perceived pressure to defend oneself increases students' perceived need to perform well in college literacy activities and to classify their childhood performance as exceptional.

\section{Literacy As Escape: Negative Experiences With Homeschooling}

So far, a majority of the authors in this study defend homeschooling as a positive literacy experience. However, several authors associate their homeschooling literacy acquisition with unpleasant or harmful memories. In four of the eighteen narratives in this study, homeschooling exacerbated difficult family dynamics. Two of these students recall literacy as their only chance to escape from isolating and abusive homes. ${ }^{5}$

One barrier to homeschooling literacy arises when a student perceives their home educator as lacking authority or unworthy of respect. This disrespect causes the student to refuse to read or write, and their negative attitudes toward their parents transfer to hatred of reading and writing. One homeschooled high school student of unspecified gender, writing under the pseudonym "BabyPrikichi," recounts failing to complete writing assignments when accountable only to their mother because she is not a "real teacher." The student constantly fought with their mother over not completing schoolwork. However, in tenth grade, the student's mother enrolled them in a writing class with other homeschooled students. In the classroom, the student's motivation improved because the classroom's authority structures and requirements became non-negotiable: "All of a sudden, I no longer had a choice. I had to write! I could not manipulate my mom any longer, and because I had a real teacher, I no longer had the option to not turn in papers. If I failed to turn in my work, I would 
get a zero and fail the class. So, because I was proud of my grades, I swallowed the pill, and did my best." The negative, extrinsic motivation-avoiding failure-is implicitly absent in this student's homeschooling setting. The writing teacher's perceived power to assign nonmanipulable grades inspires a respect that the student does not extend to their parent. In other words, BabyPrikichi looks to external authority structures to validate their literacy. The student does of course have the option of not submitting papers, but their own fear of failure (and the ways they associate grades with personal pride and identity) prevents them from even considering challenging this external authority. Though this student initially needs extrinsic motivation to begin writing, their fear of failure gives way to intrinsic motivation. After the class, BabyPrikichi and friends from the class begin to engage in spontaneous, ungraded literacy activities, independently creating a blog to publish their persuasive writing.

Tyler Eppley's literacy narrative is not uniformly negative toward homeschooling, sibling competition, or his homeschooling parents, but it relates some difficulties, doubts, and frustrations. Like BabyPrikichi, Eppley's narrative suggests some doubt about his mother's chosen educational methods. However, unlike BabyPrikichi, who feels demotivated by a lack of structure, Eppley felt defeated by rigid requirements. He writes, "Home schooling was always difficult and frustrating for me as a child." According to him, it was simpler for his mother to teach one grade, so she advanced him to the same grade as his brother, who was seventeen months older. Yet Eppley struggled, while his brother succeeded. Not feeling able to compete with his brother "caused me to turn my back on reading," and reading began to feel like punishment. To encourage him to read faster, his mother would set a timer and make him complete comprehension questions; he felt like a failure when he could not finish the comprehension questions in time, and his brother left him far behind. Even though he "wanted to learn and remain in the same grade" as his brother and avoids directly blaming his mother, Eppley implicitly criticizes her methods: selecting "dreaded reading and comprehension books," reading off "tiresome and repetitive" vowel flashcards, and creating a reading competition that caused him "discomfort and embarrassment." While sibling rivalry can be a positive literacy sponsor (as it is for Muhammad, Johnson, and Hassan), those students also recall occasionally being able to win against their older siblings. Eppley's feelings of failure in sibling competition, on the other hand, seem to stem from a sense of always being unequally matched.

In contrast, Eppley found writing freeing. He mentions the support of "the discourse community of my family" as a literacy sponsor alongside "dictionary.com" and "the synonyms application available in Microsoft Word." Writing for him carries none of the same negative associations as reading, but rather gives him a "sense of release." When this same feeling of freedom carries over into his reading, his hatred subsides into a more "relaxed dislike." He recalls self-selecting and enjoying The Lord of the Rings during his homeschooled junior high years because "I distinctly recall opening up the massive thousand plus page book and never feeling a sense of rush or doubt that I would finish it." Reading a book for fun, without the embarrassment of losing or failing in competition, frees him from his earlier feelings of defeat.

Like BabyPrikichi, Eppley finds a classroom environment with teachers and other students to be a motivating literacy sponsor. When he begins attending public high school, he encounters a variety 
of literacy sponsors and opportunities:

Now all of the sudden I was surrounded by hundreds of fellow student[s], teachers, coaches, and faculty members that I never had met before. The opportunity for my literacy to take a major turn for the better had arisen. Being home schooled and growing up in a strong Baptist family meant that I was rather sheltered as a child. Now entering into high school I was exposed to numerous foreign words and phrases, that to be honest I hadn't heard or experienced before.

In addition to participating in mainstream school culture, Eppley also benefits from the opportunity to play football and baseball in high school. His newfound interest in sports acts as a literacy sponsor: "I began to read anything I could get my hands on about football." Eppley closes by taking responsibility for his early attitude toward literacy: "Looking back I would love to have a chance to change my literacy habits in elementary school. I believe that with a little more work and dedication I could have become an avid reader that was passionate about books, magazines, newspapers, and any other type of material I could lay my hands on." The communities and interests Eppley developed in public high school, and later college, motivate him to retrospectively take ownership of his homeschool literacy acquisition and allow him to look forward to a more positive relationship with reading: "Hopefully one day I'll find that person that I lost during my childhood years of fear and doubt."

My reading of Eppley's and BabyPrikichi's narratives suggests that the difference between students who had positive and negative homeschooling experiences may not necessarily be the amount of structure that students receive. While BabyPrikichi needed more structure to be motivated to complete work, Eppley found his mother's rigid structure, flashcards, and textbooks to be punishing and restrictive. The level of structure varies among students with positive experiences as well. Some students, such as Stephen Carradini and Megan Cardenas, describe homeschooling's lack of structure as freeing. Other students, like Lynn Simmons and Komysha Hassan, positively recount their parents creating a more structured homeschooling experience, with traditional motivators such as grades and portfolios.

One difference between positive and negative experiences in this body of texts seems in part to be the amount of perceived educational authority these students invest in their parent-instructors, and how much students buy in to their parents' teaching methods. Students with positive experiences often defend their parents' qualifications to teach, while those with negative experiences implicitly question their authority and methods. For both Eppley and BabyPrikichi, traditional classroom environments fostered motivation not present in their home education environments. In both cases, their parents realized the need for this shift and adjusted their education to best fit their children's needs.

Though many of these narratives recall family environments that were warm, vibrant, and nourishing places of literacy sponsorship, homeschooling could, in certain cases, exacerbate preexisting problems of abuse or neglect. This is the case in two student narratives by Mary Katherine Swiantek and Amanda Joy. In these two narratives, however, homeschooling is not the cause of family problems - rather, it became part of a larger problem. Interestingly, both these narratives recount 
homeschooling in rural communities. Because of their geographic isolation, both students lacked the resources and communities available to homeschoolers living in more populated areas. Nevertheless, in both of these narratives, literacy also acted as a way of escape mentally, if not physically.

Mary Katherine Swiantek's narrative describes how her mother's depression often left her to complete her schoolwork alone:

I was fortunate to have a great father figure in my life, but unfortunately I didn't have that same relationship with my mother. She was young when she had me, and my brother followed just eleven months later. She stayed home to take care of us while my father worked, but soon after I was born she was diagnosed with depression. When my dad was away, home wasn't always the best place to be. Sometimes my mother would lock me out of the house because she didn't feel like dealing with me, other times she would just lock herself away in her room.

Though Swiantek's home situation was already difficult, it became worse when her family moved to a rural community and began homeschooling. She and her siblings "were completely removed from the life [they] knew," and homeschooling felt like a form of imprisonment that she wanted to escape: "I remember feeling trapped, like Belle inside the Beast's castle, I couldn't escape. I couldn't just get in the car and drive somewhere at that age. I had no friends, and wasn't in school ... . I became very depressed, and felt very alone." As a consequence of her mother's depression, a week would pass where the family would not leave the house, and literacy became her only way of escape: "When my mother would yell at me, or hit me, I ran. Not from home, but into my pages. Books weren't just words on paper; for me, they were another world." Writing her own stories became a way of coping with an abusive family situation.

In high school, Swiantek decided to attend public school. On one hand, this transition improved her situation and lessened her social isolation: "I took drama, choir, and even became editor of my school newspaper. I made friends, went to football games and homecoming dances, but I never stopped writing." However, though public school provided a way for her to make friends and temporarily escape her home, it could not entirely compensate for the abusive home environment she returned to at the end of the day. She recalls beginning to look to people, rather than books, as her means of escape. This continued desire to escape translated into a marriage at an early age that she later regretted: "I fell in love shortly after and became so invested in my relationship that I never even made time to pick up a book. My relationship became my escape, just as books always had, and it was only until after I got married that I realized I wasn't myself. My prince had finally come to take me away, but instead he took all of me away." This realization caused her to turn back to writing as a way of reclaiming her voice, of telling her story.

For another DALN writer, the literacy acquired via homeschooling also became a method of empowerment and escape from her family situation. Growing up in rural Appalachian poverty, in a home without electricity, Amanda Joy's experience differs from other narratives in this study, most of whom identified their socioeconomic background as middle class. Unlike most of the other narratives in this study, Joy's impoverished background greatly limited the number of resources available to her, and she relied mainly on self-selected books from her library's book sale. 
When Joy became a teenager, her mother remarried and joined what Joy describes as a fringe, fundamentalist group adhering to the doctrine of Christian patriarchy. Joy writes that this ideology contributed to her family's isolation: "Our lives were relegated to a tiny world in the middle of nowhere, our minds filled with the theology of Christian patriarchy and the doctrine of 'separation' from the world." Because Joy was "the eldest daughter in a family of 8," she writes, "My mother didn't have a lot of time to spend on my own home school education. Instead, I was given books with instructions to read them and write a report ... . My mother was, thankfully, acutely aware of the benefit of literature for education."

Growing up in this fringe movement, literacy became a way for Joy to subvert the dominant discourse that she received. She describes literature as her "freedom-[her] escape from the loneliness, the sterility, and the maddening indoctrination of my environment." As a result, her literacy acquisition often took place in secret. She recalls burning the first "scary" story she ever wrote because she was afraid her parents would find out: "It was the fear of telling the wrong story, of not conforming to the proper narrative, and being judged for it." Yet when she attended Berea College, a tuition-free university in Kentucky, she developed the courage to present her creative writing to others and saw literacy as a way to understand, communicate, and critique her own experience. Literacy, and studying her own literacy, continued to be her way of escape and empowerment.

Both Swiantek's and Joy's narratives suggest that homeschooling can exacerbate and perpetuate existing problems in the family structure, yet it is not necessarily the cause of those problems. Though public school brought some temporary relief for Swiantek, it did not immediately solve the problems within her family unit. Literacy, however, provided a way for both women to escape, critique, and better understand their situations.

\section{Pedagogic Violence: Transitioning To Public School}

While some narratives recount a positive transition from homeschooling to public school, others recall traditional schooling as a site of pedagogic violence. Stephanie Paterson describes the shift that can take place in students' attitudes toward reading once they transition from home to school. At home, learning is warm, imaginative, and encouraging; and then students experience a shift where reading becomes cold, hierarchical, fearful and evaluative:

These are stories marked by the presence of loving, attentive parents who offer nourishment in the form of "hot cocoa," imaginative stories and physical and emotional warmth. In the early years, reading is self-sponsored and imaginative, and it is reading conducted in relation to another person. And then, inevitably, the shift occurs in parental goals. Schools reinforce this shift in their linear forward-marching notion of literacy lessons that are divided up into hierarchical groups. Students remember the shift from storytelling to reading-forevaluation with fear and trembling. (119-120)

In the DALN narratives this study examines, writers who had positive experiences with homeschooling especially struggle with this transition because it often happens for them later in life. While they are still being homeschooled, their parents read to them for fun, and self-sponsored 
and imaginative reading continue through high school. Writing is playful, and literacy activities are less about evaluation than about creativity and encouragement. But this sense of adventure fades for some upon entering traditional school.

This is Megan Cardenas' experience with writing: "My mother taught me how to write with passion and connect with my audience on a deep personal level. She used to say, write for you, not them. She found different ways to teach us so we would really learn rather than just remember information for tests." Though Cardenas initially "begged" to go to public school the summer before she entered seventh grade, she found that it was quite different from what she had imagined. She became one among many, and she recalls feeling surprised and constrained by the rules and authority structures used in the traditional classroom to contain and patrol students' bodies: "During classes, I had to ask to use the restroom and I was assigned a seat as if I couldn't be trusted. This was new to me." She felt that her more advanced literacy background immediately marked her out from the rest of her peers in seventh grade. This made her feel smart, but also like an outsider:

As each student read his or her paper, I realized how most of the students could barely construct a simple sentence. Grammar was a disaster, sentence structure almost didn't exist, and spelling was just horrible. As I read my paper my teacher told me that it was absolutely splendid. She also asked me what school I transferred from. I told her that I had been home schooled. I was very confused. How was it that all these kids who were the same age as me, did not receive the same education I had?

Though Cardenas enjoyed some aspects of public school, she recounts that one teacher told her not to correct other students' papers "too well" and discouraged her from differentiating herself:

She also said that I had to stop writing such intricate and intelligent papers so the other classmates could understand my writing. Then it hit me like a ton of bricks. My schoolteacher wanted me to 'dumb down' my writing. I don't like this idea because, if I was such a good writer, I should be challenged and pushed to be an even better one, but apparently that was not the case in public school.

In high school, she began to believe that she "had to write for my peers and not for myself" and she stopped pushing herself to improve: "I had lost my passion for writing and I could feel my technical aspect of writing slowly disintegrate. Since I was not being challenged, I scraped by with average high school 'A' papers." In college, she recalls being told that she was "too intelligent" to peer review other students' papers, and her learning became a source of shame. She concludes, "Public school confined me into what they thought was appropriate knowledge for a student of a certain age. The whole 'No child left behind' is great in theory, but it also means 'No one march ahead."' In Cardenas' case, at least, she perceives public school, and even college, as holding her back from her full literacy potential.

Elizabeth Kent's narrative also recalls the jarring difference between her home and school learning environments. At home, she and her mom used to play a "dictionary game," where they would look up words and try to guess their meanings. When she entered public school in third grade, she announced to the teacher on the first day that her favorite word was "antidisestablishmentarianism." The teacher responded by discrediting her literacy. "I don't think that's your favorite word," she said. 
Kent recalls feeling "like even more of an outsider" as her home literacy was delegitimized: "And all of a sudden, I realized that school, and that learning, wasn't always a safe place. But at home, learning had always been a safe place, a place of adventure and discovery, but all of a sudden I'm in this place that's very combative, with a teacher who is supposed to support you in a discovery of new knowledge [and who] was in some ways attacking me in front of the entire class." When she went home from school, her mother worked to undo the teacher's damage, but Kent had already received the same message as Cardenas: "I have to fit in."

Even if a student does not narrate a teacher's discouragement, some tie their entrance into the traditional classroom to a change in their feelings about literacy. Maria McNeill entered private school at six years old as a result of trauma; her mom, who had begun homeschooling her, passed away. Though "learning to read with my mom was one of [her] many favorite childhood memories," she marks her entry into private school as the time she began to dislike reading because it "began to feel like a punishment." In her narrative, she struggles to pinpoint exactly why this change took place: "Reading was one of the most valuable memories I had with my mother as a young child. Now, the only reading I do is for school. I do not enjoy it anymore, and I have not for a long time now. How is it possible to go from loving reading so much to hating it? By this I mean to the point where the only time I truly read is when it is required." McNeill's transition resembles the move that Paterson describes from the "physical and emotional warmth" of early childhood reading toward the structure of the traditional classroom, where reading begins to feel like punishment. As Paterson observes, schools' focus on assessment, testing, and "forward-marching" can deprive some students of the love and motivation they once possessed. The trauma of this transition for McNeill is amplified by the loss of her mother, whom she identifies as her primary literacy sponsor. Yet McNeill nevertheless describes her loss of love for reading as mysterious, perhaps inexplicable: "Why reading felt like a punishment to me, I still do not know."

In some cases, homeschooling preserves a love for reading through early adulthood-which may explain why Cynthia Drenovsky and Isaiah Cohen find that the formerly homeschooled college students have a significantly more positive view of their college experience than do their traditionallyeducated peers. Though still structured, college allows for much more self-directed learning than the typical high school, and homeschoolers may be able to flourish because they are already accustomed to an environment that encourages creativity and self-direction.

\section{Conclusion}

From eighteen narratives, it is of course impossible to generalize about the 1.8 million students currently homeschooled in the United States. However, these stories do add data points to the range of literacy activities and experiences that homeschooling enables. In these narratives, homeschoolers often operate in reference to the dominant educational discourse; yet they redefine this discourse in creative and memorable ways. Many homeschooling families cultivate a rich environment of literacy sponsorship, blending literacy with daily life activities rather than creating a divide between "home" and "school." Those who report negative experiences with homeschooling did so primarily because 
they perceived their home educators as lacking the socially recognized authority of a traditional classroom. While homeschooling also has the potential to isolate children and exacerbate negative family environments, the two narratives that record this experience seem to be an exception rather than a rule. In fact, more students record a negative experience transitioning from homeschooling into traditional school environments, where they feel that they lost their creativity, freedom, and joy in literacy activities.

As many young adults from homeschooling backgrounds pursue undergraduate and graduate education, their experiences with literacy provide fertile ground for further research. Do homeschoolers disproportionately pursue higher education partly as a way to further legitimize their literacy? Is there a correlation between homeschooling and a need to defend one's literacy, and what are the long-term effects of this urge? Are there common threads among homeschoolers' rich and varied experiences with literacy? How can we protect children like Amanda Joy and Mary Katherine Swiantek from abuse? And how can we promote the positive homeschooling literacy experiences of students like Muhammad, Hassan, and many others? More quantitative and qualitative research is necessary to begin to answer these questions as we seek to better understand the literacy of 1.8 million American students.
"Those who report negative experiences with homeschooling did so primarily because they perceived their home educators as lacking the socially recognized authority of a traditional classroom. While homeschooling also has the potential to isolate children and exacerbate negative family environments, the two narratives that record this experience seem to be an exception rather than a rule. In fact, an equal number of students record a negative experience transitioning from homeschooling into traditional school environments, where they feel that they lost their creativity, freedom, and joy in literacy activities." 


\section{NOTES}

${ }^{1}$ Kristin D. Jones et al. define "unschoolers" as those who entirely "reject the structured learning of schooling, formal curricula, and testing" in favor of an unstructured, child-directed approach to learning $(392,397)$.

${ }^{2}$ Elmborg also recognizes that the rules of these "dominated spaces" restrict access for "borderland students whose cultural pasts are shaped by social structures that differ from the school norm" (347); however, he argues that the library has the potential to bring discourses into dialogue in order to "challenge and reshape both academic content literacy practices and the knowledges and Discourses [sic] of youth's everyday lives" (347).

${ }^{3}$ One example is Tyler Eppley's narrative, discussed in the third section. His mother relied on more traditional educational methods, like flash cards and timed comprehension questions, and he views his homeschooled education more negatively than students whose educators revised traditional tools.

${ }^{4}$ The narratives that I categorize as "child prodigy" narratives are those by Dallas Reynolds, Bethany Frantsen, Jeremiah Harbour, Carlee Mabrey, Elisa Johnson, and Komysha Hassan. Two others portray their learning as exceptional but received punishment for displaying this learning in public because it was far ahead of others (Megan Cardenas and Elizabeth Kent); these are discussed in the final section. Other narratives, such as that of Gingerich Destiny, discuss reading advanced works at an early age (Jane Eyre at 11), but I do not consider them "child prodigy" narratives because they do not mention performing these literacy skills for others.

${ }^{5}$ The narratives that reflect negative experiences with homeschooling are those by Tyler Eppley, BabyPrikichi, Mary Katherine Swiantek, and Amanda Joy. 


\section{WORKS CITED}

Alexander, Kara Poe. "Successes, Victims, and Prodigies: 'Master' and 'Little' Cultural Narratives in the Literacy Narrative Genre." College Composition and Communication 62.4 (2011): 60833. Print. https://www.jstor.org/stable/23006908.

Altieri, Jennifer L. "From McGuffey Readers to Taking Notes on the Sermon: Literacy Experiences in a Catholic Home Schooling Group." Reading Horizons 41.2 (2000): 105-16. Print.

BabyPrikichi. "My Writing Class." Digital Archive of Literacy Narratives. Web. 24 Oct. 2018. http:// www.thedaln.org/\#/detail/ab8a2c49-5bbb-4a7a-940b-cf03b66a392f.

Baxter, Judith. Double-Voicing at Work: Power, Gender and Linguistic Expertise. London: Palgrave Macmillan, 2014. Print.

Brandt, Deborah. Literacy in American Lives. Cambridge: Cambridge UP, 2001. Print.

Bryson, Krista. "The Literacy Myth in the Digital Archive of Literacy Narratives." Computers and Composition 29.3 (2012): 254-68. Print. https://doi.org/10.1016/j.compcom.2012.06.001.

Cardenas, Megan. "Home Schooled Literacy." Digital Archive of Literacy Narratives. Web. 24 Oct. 2018. http://www.thedaln.org/\#/detail/54ecf71a-68a6-4279-af40-bfa8811db7c9.

Carradini, Stephen. "How to Start a Blog (No Matter If You've Never Read One)." Video. Digital Archive of Literacy Narratives. Web. Accessed 24 Oct. 2018. http://www.thedaln.org/\#/ detail/e192fc3e-c15b-49f2-93a9-b4a0c47fb022.

Drenovsky, Cynthia K., and Isaiah Cohen. "The Impact of Homeschooling on the Adjustment of College Students." International Social Science Review 87.1-2 (2012): 19-34. https://www.jstor.org/stable/41887517.

Elmborg, James K. "Libraries as the Spaces Between Us: Recognizing and Valuing the Third Space." Reference \& User Services Quarterly 50.4 (2011): 338-50. Print. https://doi.org/10.5860/ rusq.50n4.338.

Eppley, Tyler. "Ohio University Student's Literacy Narrative." Digital Archive of Literacy Narratives. Web. 24 Oct. 2018. http://www.thedaln.org/\#/detail/47293129-1e06-4df0-bfdd$7 \mathrm{ff} 269 \mathrm{bc} 58 \mathrm{ff}$.

Fleming, Julia. “The Chapters of my Life." Digital Archive of Literacy Narratives. Web. 24 Oct. 2018. http://www.thedaln.org/\#/detail/47b1e85f-6069-493a-9b0f-dca2a9bed45c.

Foss, Sonja K. Rhetorical Criticism: Exploration and Practice. 3rd ed. Long Grove: Waveland P, 2004. Print.

Frantsen, Bethany. "Journaling and Learning to Write." Digital Archive of Literacy Narratives. Web. 24 Oct. 2018. http://www.thedaln.org/\#/detail/bd682c25-3fea-42c1-9cea-c2038a1bc600.

Gingerich, Destiny. "Reading." Video. Digital Archive of Literacy Narratives. Web. 24 Oct. 2018. http://www.thedaln.org/\#/detail/b6aa3b3b-50a3-4e8e-a8bb-ccb07c8e1812.

Grady, Sarah. "Measuring the Homeschool Population." NCES Blog. 4 Jan. 2017. Web. 22 Oct. 2018. https://nces.ed.gov/blogs/nces/post/measuring-the-homeschool-population.

Harbour, Jeremiah. "A Journey into Literature." Digital Archive of Literacy Narratives. Web. 24 Oct. 2018. http://www.thedaln.org/\#/detail/49353a7a-blaa-427f-8548-7fdcce7e0b98.

Hart, Roderick P. "Wandering with Rhetorical Criticism." Critical Questions: Invention, Creativity, 
and the Criticism of Discourse and Media. Eds. William L. Nothstine, Carole Blair, and Gary A. Copeland. New York: St. Martin's, 1994. Print.

Hassan, Komysha. "Righting History." Digital Archive of Literacy Narratives. Web. 24 Oct. 2018. http://www.thedaln.org/\#/detail/7cda3f2b-30de-4a1e-8c34-30c0245e1d37.

Johnson, Elisa. "Home-Schooled Spelling Bee." Video. Digital Archive of Literacy Narratives. Web. 24 Oct. 2018. http://www.thedaln.org/\#/detail/894dca09-6144-4b22-a724-bada38c39034.

Jones, Kristin D., Cynthia Cole Robinson, and Kelly P. Vaughan. "Deschooling, Homeschooling, and Unschooling in the Alternative School Milieu." The SAGE Guide to Curriculum in Education. Eds. Ming Fang He, Brian D. Schultz, and William H. Schubert. Los Angeles: SAGE Publications, 2015. 391-399. Print.

Joy, Amanda. “The Literacy of Rural Poverty." Digital Archive of Literacy Narratives. Web. 24 Oct. 2018. http://www.thedaln.org/\#/detail/e6defde0-31bb-4763-bf14-9c55b9016bb8.

Kent, Elizabeth. “Antidisestablishmentarianism." Video. Digital Archive of Literacy Narratives. Web. 24 Oct. 2018. http://www.thedaln.org/\#/detail/9a7eeb72-683f-456f-81f0-5aa68335e030.

Lines, Patricia M. “Homeschooling Comes of Age.” The Public Interest (2000): 74-85. Print.

Mabrey, Carlee. "Me vs. Everyone: Why Being an English Major Makes Me Smarter Than Everyone Else." Digital Archive of Literacy Narratives. Web. 24 Oct. 2018. http://www.thedaln.org/\#/ detail/59834035-bbb4-4513-a1b9-9ff59d8c1825.

Marzluf, Phillip P. "Writing Home-Schooled Students into the Academy." Composition Studies 37.1 (2009): 49-66. JSTOR. Web. http://www.jstor.org/stable/43501756.

---. "Literacy, Home Schooling, and Articulations of the Public and the Private." Community Literacy Journal 4.2 (2010): 75-98. Print.

McNeill, Maria. "All About My Life." Digital Archive of Literacy Narratives. Web. 24 Oct. 2018. http:// www.thedaln.org/\#/detail/57cb8480-e76e-446c-97c5-85394d227efa.

Muhammad, Muslimah. “Fond Memories.” Digital Archive of Literacy Narratives. Web. 24 Oct. 2018. http://www.thedaln.org/\#/detail/93962a1f-fa4b-4151-aff1-8400a0ac469e.

Nemer, Kariane Mari. "Understudied Education: Toward Building a Homeschooling Research Agenda." Occasional Paper No. 48. National Center for the Study of Privatization in Education, 2002. Print.

Paterson, Stephanie. Embodied Narratives: Ways of Reading Student Literacy Histories. Diss. U of New Hampshire, 2001. Web. Retrieved from ProQuest Digital Dissertations (UMI 3006147).

Payton, Karl E., and Joyce A. Scott. "Communication Apprehension Among Homeschooled College Freshmen." FOCUS on Colleges, Universities \& Schools 7.1 (2013): 1-10.

Redford, Jeremy, Danielle Battle, Stacey Bielick, and Sarah Grady. "Homeschooling in the United States: 2012." US Department of Education. National Center for Education Statistics, 2016. https://nces.ed.gov/pubs2016/2016096rev.pdf.

Reynolds, Dallas. “Dallas' Literacy Narrative.” Video. Digital Archive of Literacy Narratives. Web. 24 Oct. 2018. http://www.thedaln.org/\#/detail/bf8bff84-1fdd-452b-ad85-4a27a227deb1.

Romanowski, Michael H. "Revisiting the Common Myths About Homeschooling." The Clearing House 79.3 (2006): 125-129. https://doi.org/10.3200/TCHS.79.3.125-29. 
SanClemente, Jeanine. College Transition Experiences of Women Who Were Homeschooled: A Phenomenological Study. Diss. Walden U, 2016. Web. Retrieved from ProQuest Digital Dissertations (UMI 10164252).

Simmons, Lynn. "Home School and Literacy." Video. Digital Archive of Literacy Narratives. Web. 24 Oct. 2018. http://www.thedaln.org/\#/detail/1e34388f-f996-4b41-ba6d-9ed54c6b0d32.

Snyder, Marc. "An Evaluative Study of the Academic Achievement of Homeschooled Students Versus Traditionally Schooled Students Attending a Catholic University." Journal of Catholic Education 16.2 (2013): 288-308. https://doi.org/10.15365/joce.1602042013.

Swiantek, Mary Katherine. “Finding My Voice.” Digital Archive of Literacy Narratives. Web. Accessed 24 Oct. 2018. http://www.thedaln.org/\#/detail/9bd5889b-2948-4deb-8cf2-f7ae7056f193.

Van Galen, Jane A. "Explaining Home Education: Parents' Accounts of Their Decisions to Teach Their Own Children." The Urban Review 19.3 (1987): 161-77. https://doi.org/10.1007/ BF01111877.

---. "Ideology, Curriculum, and Pedagogy in Home Education." Education and Urban Society 21.1 (1988): 52-68. https://doi.org/10.1177/0013124588021001006.

Wooten, Courtney Adams. Blurring the Lines: Teaching Literacies in Home/School Spaces. Diss. U of North Carolina at Greensboro, 2014. Web. Retrieved from ProQuest Digital Dissertations (UMI 3624164).

Worsham, Lynn. “Emotion and Pedagogic Violence.” Discourse 15.2 (1992): 119-48. JSTOR. Web. www.jstor.org/stable/41389271. 